\title{
PELATIHAN KEWIRAUSAHAAN DAN KOPERASI BERBASIS SYARIAH BAGIPELAKU UMKM DI CEMPAKA PUTIH JAKARTA PUSAT
}

\author{
Muslikh $^{1}$, Lily Deviastri' ${ }^{2}$, Rini Hidayati ${ }^{3}$ \\ ${ }^{1}$ FakultasEkonomi Universitas YARSI Jakarta 1 \\ ${ }^{2,3}$ FakultasEkonomi Universitas YARSI Jakarta2 \\ ${ }^{1}$ Email: muslikh@yarsi.ac.id
}

\begin{abstract}
The purpose ofthisprogramis to raise awarenessandentrepreneurialskillsfor SMEs enterprise.The method usedis byapproachingthe SMEs enterpriseto identifythe problemsfaced bythem. The training methods were given by lectures anddiscussionsaboutentrepreneurship. The resultis the increasing of awarenessand understanding ofentrepreneurshipincluded:finance, banking, accounting, marketing, productionand cooperatives. Therefore,entrepreneurship training for SMEs enterprise should be donecontinuously, thus increasingsales turnover.
\end{abstract}

Keyword: Training, Entrepreneurship, Cooperation, Based on Syariah, SMEs Enterprise

\begin{abstract}
Abstrak. Tujuan program ini adalah untuk meningkatkan kesadaran dan kemampuan kewirausahaan dan perkoperasian bagi pelaku usaha kecil (UMKM). Metode yang dipergunakan adalah mengadakan pendekatan dengan mitra pelaku usaha kecil untuk mengidentifikasi permasalahan-permasalahn yang dihadapi UMKM. Metode pelatihan dengan ceramah dan diskusi tentang kewirausahan dan perkoperassian berbasis dsyariah. Hasil yang dicapai adalah meningkatnya kesadaran dan pemahaman tentang kewirausahan dan perkoperasian berbasis syariah yang meliputi aspek: keuangan syariah, perbankan syariah, akuntansi syariah, pemasaran online. Pelatihan kewirausahaan dan koperasi berbasis syariah bagi pelaku usaha kecil perlu dilakukan secara berkesinambungan untuk meningkatkan kinerja UMKM.
\end{abstract}

Keyword: Pelatihan, Kewirausahaan, Koperasi , Berbasis Syariah, UMKM

\section{PENDAHULUAN}

1. Analisis Situasi

Pembangunan di bidang ekonomi merupakan salah satu prioritas utama dan menjadi tujuan utama pembangunan yang dilaksanakan di Indonesia. Tujuan akhir dari upaya pembangunan ekonomi yang dilaksanakan pemerintah ialah bagaimana agar masyarakat Indonesia mencapai adil dan kmur. Keadilan dan kemakmuran akan diperoleh jika setiap pilar ekonomi bangsa berperan aktif dalam proses pembangunan.

Agar Usaha UMKM tetap eksis dan meningkat kinerjanya dari waktu ke waktu, maka diperlukan ikhtiar dengan belajar ilmu yang berkaitan dengan kewirausahaan, pemasaran, perkoperasian dan sebagainya. UMKM mempunyai keunggulan dibandingkan dengan usaha besar antara lain fleksibelitas dan cepat beradaptasi dengan perubahan pasar, mampu menyerap tenaga kerja (unskilled labour) relatif besar, Mayoritas UMKM menghasilkan barang konsumsi dan jasa dengan elastisitas permintaan terhadap pendapatan yang rendah.Dengan mayoritas penduduk Indonesia memiliki pendidikan rendah, kemampuan UMKM dalam menyerap tenaga kerja unskilled labour sangat membantu dalam menciptakan lapangan kerja.

Koperasi merupakan salah satu pilar penting sistem ekonomi Indonesia. Namun demikian keberadaan koperasi yang ada tidaklah seimbang jika dibandingkan dengan perusahaanperusahaan swasta yang ada. Terbatasnya jumah koperasi berbasis syariah disebabkan oleh kurangnya pemahaman tentang koperasi baik dari aspek pendirianya maupun aspek manajemen koperasi. Untuk memajukan UMKM salah satu caraanaya adalah dengan mendirikan koperasi berbasis syariah bagi UKM. Dengan memiliki koperasi berbasis syariah, diharapkan dapat menunjang kegiatan bisnis UMKM. Dewasa ini koperasi yang berbasis syariah sedang diminati oleh masyarakat, termasuk didalamnya adalah pelaku UMKM.

Berdasarkan survey pendahuluan tentang keberadaan usaha mikro (UMKM) di DKI Jakarta berdasarkan wilayah pada tahun 2015 ada 4.684 unit usaha . Berdasarkan wilayah, Jakarta 
selatan memiliki usaha mikro terbesar yaitu 25.9

\%, Jakarta pusat $24.9 \%$ dan Jakarta timur 19.1
$\%$. Untuk lebih jelasnya disajikan dalam Table-

1 berikut:

Tabel 1. Jumlah Usaha Mikro di DKI Menurut Wialayah

\begin{tabular}{llll}
\hline No & Wilayah & Juamlah & Proseentase \\
\hline 1 & Jakarta Selatan & 1.212 & $25.9 \%$ \\
\hline 2 & Jakarta Pusat & 1.165 & $24.9 \%$ \\
\hline 3 & Jakarta Timur & 893 & $19.1 \%$ \\
\hline 4 & Jakarta Barat & 808 & $17.3 \%$ \\
\hline 5 & Jakarta Utara & 806 & $12.9 \%$ \\
\hline & JUMLAH & 4.684 & $100 \%$ \\
\hline
\end{tabular}

Sumber : Dinas UMKM, Perdagangan dan Koperasi, 2015

Bila ditinjau berdasarkan sector usaha, sektor perdagangan masih dominan yaitu mencapai 1.778 unit usaha, diikuti usaha aneka jasa 1.445 unit, kerajinan sebanyak 732 unit, sektor makanan 430 unit, produk lainya 299 unit. Data tersebut disajikan pada Table- 2 berikut

Tabel 2. Jumlah Usaha Mikro di DKI Menurut Bidang Usaha

\begin{tabular}{clcc}
\hline No & \multicolumn{1}{c}{ Wilayah } & Juamlah & Proseentase \\
\hline 1 & Perdagangan ritail & 1.778 & $38.0 \%$ \\
\hline 2 & Aneka Jasa & 1.445 & $30.8 \%$ \\
\hline 3 & Kerajinan & 732 & $15.6 \%$ \\
\hline 4 & Makanan olahan & 430 & $9.2 \%$ \\
\hline 5 & Produk lainya & 299 & $6.4 \%$ \\
\hline & JUMLAH & 4.684 & $100 \%$
\end{tabular}

Sumber : Dinas UMKM, Perdagangan dan Koperasi, 2015

Berdasarkan wilayah, Jakarta Pusat merupakan urutan kedua setelah Jakarta Selatan dalam jumlah usaha mikro.Wilayah Cempaka Putih tempat akan dilaksanakan PkM merupakan bagian dari Wilayah Jakarta Pusat. Bila ditinjau dari jenis usaha, yang paling dominan juga jenis usaha perdagangan. Oleh karena itu yang akan menjadi target dalam PkM ini adalah sebagaian besar dari jenis usaha perdagangan.

Bahwa program PkM ini berbasis research yang pernah dilakukan oleh tim pada tahun 2015/2016. Hasil research menunjukkan bahwa orientasi kewirausahaan, orientasi pasar pelaku UMKM di Cempaka Putih masih rendah. Oleh karena itu tim PkM melakukan identifikasi permasalahaan yang dihadapi UMKM di Cempaka Putih yang ditunjukkan dalam karakteristik yang melekat pada sebagaian besar UMKM dan menjadi sumber permasalahan yang dihadapi pelaku UMKM, antara lain:

a. Rendahnya pemahaman tentang orientasi kewirausahaan dan orientasi pasar.

b. Rendahnya pemahaman tentang orientasi pasar (orientasi konsumen dan orientasi persaingan) c. Belum mempunyai Koperasi yang berbadan hukum

d. Rendahnya produktivitas tenaga kerja, mutu barang yang dihasilkan relatif rendah (belum sertifikasi/standar),

e. Minimnya kreativitas, minimnya inovasi dan adopsi teknologi baru dalam produksi,

f. Masih rendahnya pengetahuan perbankan

g. Masih rendahnya kualitas sumberdaya manusia yang bekerja pada sektor UMKM, Bertolak dari latar belakang dan analisis situasi tersebut di atas, maka tim PkM Fakultas Ekonomi Universitas YARSI bermaksud mengadakan program pengabdian kepada masyarakat $(\mathrm{PkM})$ berupa pelatihan kewirausahaan dan pendirian koperasi berbasis syariah bagi pelaku UMKM di Cempaka Putih Jakarta Pusat. Pelatihan tersebut ditargetkan dapat meningkatkan wawasan, dan pengetahuan kewirausahaan serta perkoperasian berbasis syariahbagipelaku UMKM Ceampaka Putih Jakarta Pusat

\section{Landasan Teori}

Pemberdayaan Usaha Mikro Kecil menengah (UMKM) merupakan salah satu 
alternatif yang dipilih pemerintah dalam upaya mengurangi pengangguran, mengentasan kemiskinan dan pemerataan pendapatan. Pembangunan dan pertumbuhan UMKM merupakan penggerak bagi pembangunan dan pertumbuhan ekonomi suatu negara. Perkembangan UMKM yang baik maka akan membawa kemajuan bagi perekonomian suatu negara.

Pemerintah Indonesia telah menetapkan serangkaian kebijakan dan rencana aksi untuk mendukung program-program peningkatan kualitas dan kuantitas kewirausahaan di Indonesia, agar mampu menjadi salah satu pilar ekonomi nasional yang yang dipilih pemerintah dalam upaya mengurangi pengangguran, mengentasan kemiskinan dan pemerataan pendapatan. Pembangunan dan pertumbuhan UMKM merupakan penggerak bagi pembangunan dan pertumbuhan ekonomi suatu negara. Perkembangan UMKM yang baik maka akan membawa kemajuan bagi perekonomian suatu negara.

Pengertian Usaha Mikro, Kecil dan Menengah (UMKM) menurut Kementerian Negara Koperasi dan Usaha Kecil Menengah yaitu suatu entitas usaha yang memiliki kekayaan bersih antara Rp. 200.000.000,- sampai dengan Rp. 10.000.000.000,- tidak termasuk tanah dan bangunan tempat usaha dan memiliki penjualan bersih tahunan sekitar Rp. 1.000.000.000,-. Persentase jumlah usaha kecil dan menengah menurut Kamar Dagang Indonesia (KADIN) adalah sebesar $99 \%$ dari total unit usaha yang ada di Indonesia, angka tersebut setara dengan 51,26 juta unit usaha.

Usaha Mikro Kecil dan Menengah (UMKM) mempunyai peran yang paling penting dalam menggerakkan perekonomian nasional dengan menyumbang 53\% dari PDB Indonesia pada tahun 2013. Selain itu, sektor industri kecil dan menengah memiliki kontribusi yang nyata bagi pengentasan masalah pengangguran dan masalah perekonomian. Bahwa peran sektor UMKM sangat penting karena mampu menciptakan pasar-pasar, mengembangkan perdagangan, mengelola sumber alam, mengurangi kemiskinan, membuka lapangan kerja, membangun ekonomi masyarakat dan menghidupi keluarga mereka tanpa kontrol dan fasilitas dari pihak pemerintah daerah yang memadai.Usaha Mikro Kecil dan menengah (UMKM) telah tumbuh dan berkembang dengan cepat dari waktu kewaktu. UMKM memiliki peran penting dalam perekonomian Indonesia melalui penciptaan lapangan kerja, pemerataan pendapatan, dan pengentasan rakyat dari kemiskinan. Melihat peran pennting tersebut maka dibutuhkan dukungan dari seluruh pihak untuk mngembangkan UMKM di Indonesia.

Koperasi adalah badan hukum yang didirikan oleh orang perorangan atau badan hukum Koperasi, dengan pemisahan kekayaan para anggotanya sebagai modal untuk menjalankan usaha, yang memenuhi aspirasi dan kebutuhan bersama di bidang ekonomi, sosial, dan budaya sesuai dengan nilai dan prinsip Koperasi ( UU No.17 Tahun 2012). Sebagaimana sistem perbankan yang dibedakan menjadi 2 yaitu perbankan konvensional dan perbankan syariah, maka koperasi yang beroperasi di Indonesia juga memiliki 2 jenis yaitu koperasi konvensional dankoperasi berbasis syariah.

Koperasi berbasis syariah adalah badan usaha koperasi yang menjalankan usahanya dengan prinsip-prinsip syariah. Koperasi syariah Indonesia merupakan koperasi sekunder yang beranggotakan koperasi syariah primer yang tersebar di Indonesia. Terdapat perbedaan yang signifikan antara koperasi konvensional dengan koperasi yang berbasis syariah.

Dalam Koperasi Konvensional, dicirikan :

1. Balas jasa modal dengan sistem bunga/riba

2. Tidak ada batasan produk halal \& haram

3. Tidak terikat dengan nilai-nilai ada tidaknya ketidakadilan \& kezaliman, misalnya kerusakan lingkungan, menzalimi harkat martabat manusia dan sebagainya.

4. Tidak memperhatikan aspek kegiatan zakat infak shadaqah dan wakaf

5. Pengawasan hanya pad kinerja

6. Hanya ada 1 akad, yakni bunga. Misalnya. mengkreditkan barang \& 
anggota wajib melunasi pokok + bunga tanpa kecuali

Sedangkan dalam koperasi yang berbasis syariah, cirinya antara lain:

1. Bagi hasil, diharamkan maisir, gharar\& riba

2. Produk, jasa dan rangkaian seluruh produksi konsumsi dan distribusi yang dijual harus yang halal

3. Mengedepankan keadilan dan melarang kezaliman, baik terhadap manusia maupun alam semesta

4. Sebagai institusi ziswaf yaitu menerima dan menyalurkan zakat infak shadaqah dan wakaf, dan menganjurkan pada anggota.

5. Pengawasan padakinerja dan aspek syariah

6. Akad murabahah/menjual, ijarah/ menyewa dan atau syirkah/bagi hasil atas barang \& jasa secara riil.

Koperasi Simpan Pinjam (KOSIPA) adalah sebuah koperasi yang modalnya diperoleh dari simpanan pokok dan simpanan wajib para anggota koperasi. Kemudian modal yang telah terkumpul tersebut dipinjamkan kepada para anggota koperasi dan terkadang juga dipinjamkan kepada orang lain yang bukan anggota koperasi yang memerlukan pinjaman uang, baik untuk keperluan komsumtif maupun untuk modal kerja. Kepada setiap peminjam, KOSIPA menarik uang administrasi setiap bulan sejumlah sekian persen dari uang pinjaman.

Secara umum ruang lingkup kegiatan usaha koperasi simpan pinjam adalah penghimpunan dan penyaluran dana yang berbetuk penyaluran pinjaman terutama darai dan untuk anggota. Pada perkembanganya memang koperasi simpan pinjam melayani tidak saja anggota tetapi juga masyarakat

\section{METODE PELAKSANAAN}

Yang menjadi target dalam Program PkM ini adalah pelaku usaha mikro (UMKM) di Cempaka Putih Timur Jakarta Pusat. Berdasarkan data Sudin UMKM, Koperasi dan Perdagaangan, ada 265 unit usaha mikro (UMKM) di Cempaka Putih. Namun demikian yang menjadi binaan Sudin UMKM, Koperasi dan Perdagangan Jakarta Pusat sebanyak 34 unit usaha. Pada kegiatan PkM ini jumlah sasaran yang akan dilibatkan dalam program $\mathrm{PkM}$ ini sebanyak 34 unit usaha yaitu UMKM JP- 42.

Pelaksanaan program kegiatan ini dengan pendekatan pelatihan yang diperluas. Pelatihan merupakan salah satu kegiatan yang dapat meningkatkan kualitas atau kompetensi tertentu.Adapun dalam konteks ini, pelatihan yang dimaksud adalah memberikan beberapa pengetahuan dan transfer pengalamanserta pembelajaran kepada pelaku UMKM di Cemapaka Putih Jakarta Pusat. Adapun tujuan pelatihan dalam bidang kewirausahaan dan perkoperasian adalah meningkatkan wawasan tentang kewirausahaan dan perkoperasian terutama yang berbasis syariah. Kegiatan tersebut secara eksplisit, yakni berupa adanya pertemuan dan komunikasi yang intensif antara tim pelaksana pengabdian dengan koordinator $\mathrm{PkM}$ secara bersama-sama melaksanakan analisis situasi, identifikasi kebutuhan, membuat perencanaan, melaksanakan program dan evaluasi program. Kesepakatan-kesepakatan yang telah dibuat bersama antara tim palaksana dari PkM FE YARSI dengan koordinator UMKM , tentang materi pelatihan dan monitoring langsung secara berkala dari pihak tim pelaksana PkM. Secara operasional metode pelaksanaan program $\mathrm{PkM}$ untuk yang digunakan dalam rangka memecahkan masalah yang dihadapi UMKM di atas, yakni melalui tahapan sebagai berikut.

a. Analisis situasi dan identifikasi kebutuhan UMKM

b. Perencanaan program dengan mempertimbangkan aspek sarana, prasarana, dosen, pelaku UMKM.

c. Evaluasi program dilakukan untuk mengetahui sejauh mana ketercapaian pelaksanaan kegiatan pelatihan. Evaluasi kegiatan dilakukan selama proses kegiatan berlangsung, yaitu pada saat peserta kegiatan mengikuti pelatihan. Selain itu, melakukan wawancara yaitu memberikan pertanyaan yang terkait dengan pelaksanaan pelatihan secara individu.Hal ini dilakukan untuk mengetahui bagaimana tanggapan peserta tentang pelaksanaan kegiatan pelatihan 
kewirausahaan.Dengan adanya evaluasi ini, tim pelaksana kegiatan pelatihan dapat meyimpulkan bahwa kegiatan pelatihan kewirausahaan dapat menambah dan meningkatkan pengetahuan para pelaku UMKM

\section{HASIL DAN PEMBAHASAN}

1. Hasil Pengabdian kepada Masyarakat Sebagaian besar (68\%) pelaku UMKM adalah laki laki. Hal ini sejalan dengan kewajiban bagi laki laki untuk mencari nafkah.

Tabel 3. Gambaran Umum Mitra Berdasarkan Jenis Kelamin

\begin{tabular}{lcc}
\hline \multicolumn{1}{c}{ Jenis Kelamin } & Frekuensi & Persentase \\
\hline Laki-Laki & 23 & $68 \%$ \\
\hline Perempuan & 11 & $32 \%$ \\
\hline Total & 34 & $100 \%$ \\
Sumber: Data primer diolah
\end{tabular}

Tabel.4 Gambaran Umum Mitra Berdasarkan Usia

\begin{tabular}{lcc}
\hline \multicolumn{1}{c}{ Usia } & Frekuensi & Persentase \\
\hline$<20$ tahun & & \\
\hline 21 s.d. 30 tahun & & \\
\hline 31 s.d. 40 tahun & 20 & $59 \%$ \\
\hline 41 s.d. 50 tahun & 6 & $18 \%$ \\
\hline$>50$ tahun & 8 & $24 \%$ \\
\hline Total & 34 & $100 \%$ \\
\hline
\end{tabular}

Sumber: Data primer diolah

Ditinjau dari usia, sebagaian besar peseta berusia (24\%) dan yang berusia antara 41 sampai 50 antara 31 sampai dengan 40 tahun ( 59\%). tahun sebesar 18\%.

Kemudian disusul yang berusia di atas 50 tahun

Tabel 5. Gambaran Umum Mitra Berdasarkan Umur Usaha

\begin{tabular}{rcc}
\hline Umur Usaha & Frekuensi & Persentase \\
\hline 1 s.d. 5 tahun & & \\
\hline 6 s.d. 10 tahun & 9 & $26 \%$ \\
\hline 11 s.d. 15 tahun & 14 & $41 \%$ \\
\hline 16 s.d. 20 tahun & 6 & $18 \%$ \\
\hline$>21$ tahun & 5 & $15 \%$ \\
\hline Total & 34 & $100 \%$ \\
\hline
\end{tabular}

Sumber: Data primer diolah

Tabel 6. Gambaran Umum Mitra Berdasarkan Tingkat Pendidikan

\begin{tabular}{lcr}
\hline \multicolumn{1}{c}{ Tingkat Pendidikan } & Frekuensi & Persentase \\
\hline SD & 4 & $12 \%$ \\
\hline SLTP & 20 & $59 \%$ \\
\hline SMU & 10 & $29 \%$ \\
\hline S1 & - & $\%$ \\
\hline Total & 34 & $100 \%$ \\
\hline
\end{tabular}

Sumber: Data primer diolah

Sebagaian besar pelaku usaha mikro berusia 31 s/d 40 tahun. Sedangkan waktu atau lama berusaha antara $11 \mathrm{~s} / \mathrm{d} 15$ tahun. Dilihat dari pendidikan, sebagaian besar berpendidikan lulus SLTP

Kegiatan pelatihan ini dilaksanakan atas kerjasama antara Koordianator Pengabdian 
kepada Masyarakat FE YARSI dengan koordinator UMKM Cempaka Putih.Pelatihan kewirausahaan ini dikuti oleh 400 peserta, para peserta merupakan pelaku UMKIM di Cempaka Putih. Para peserta terlihat sangat antusias dalam menikuti pelatihan ini, hal ini ditandai dengan banyaknya pertanyaan-pertanyaan yang dilontarkan oleh peserta kepada tim pelaksana mengenai mteri yanag diberikan

Seluruh peserta merasa senang, karena telah mendapatkan ilmu kewirausahaan .Dalam pelatihan ini pula disamping mensosialisasikan Lembaga Pengabdian Masyarakat FE YARSI selaku pelaksanan kegiatan, tim juga mensosialisasikan Program Studi di Fakultas Ekonomi. Hasil dari pelatihan kewirausahaan adalah meningkatnya wawasan pelaku UMKM Cempaka Putih yang sebelumnya belum memahami pengetahuan kewirausahaan, sekarang sudah mengetahui pengetahuan kewirausahaan .

Tempat Lokasi Usaha UMKM di Cempaka Putih Yang tergabung dalam JP-41 dan JP-42 merupakan lokasi sementara (loksem). Lokasi sementara yang ada pada bahu jalan mendapat ijin dari Walikota Jakarta Pusat. Ijin setiap tahun diperbaharui dalam arti bila tempat tersebut akan dipakai sebagaimana mestinya sebagai jalan umum maka lokasi sementara tersebut bisa dicabut.

Oleh karena itu perlu penataan lokasi sehingga menjadi lokasi usaha yang rapi, bersih dan nyaman, tidak kumuh. Penantaan dimulai dari pembuatan tempat usaha (tenda) yang homogen dengan warna biru dan orange. Kemudian penataan lokasi dengan tenda yang relative permanen kerjasama antara berbagi macam pihak dengan CSR dari perusahaan. Berikut penataan yang dimaks

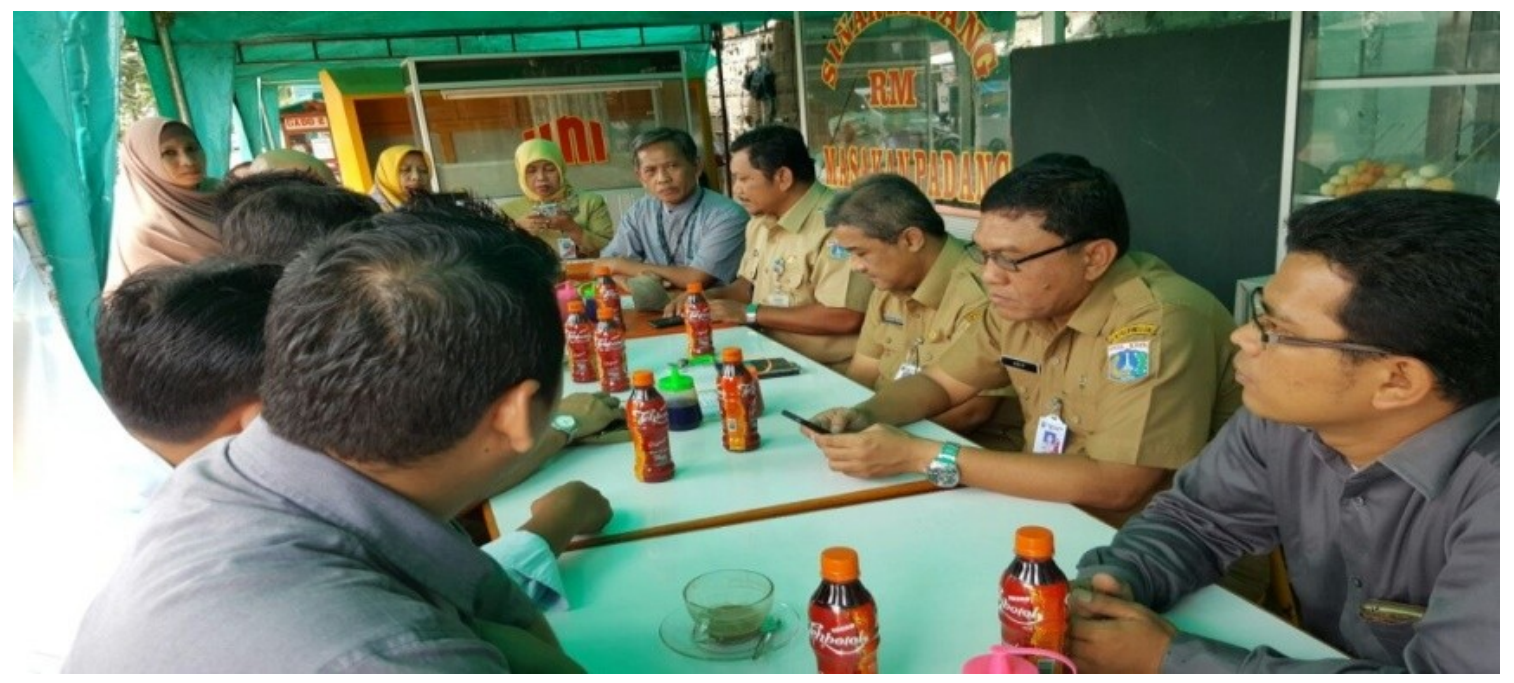

Gambar 1. Ketua Tim PkM sedang diskusi dengan Lurah, Camat, Sudin UMKM untuk penataan UMKM

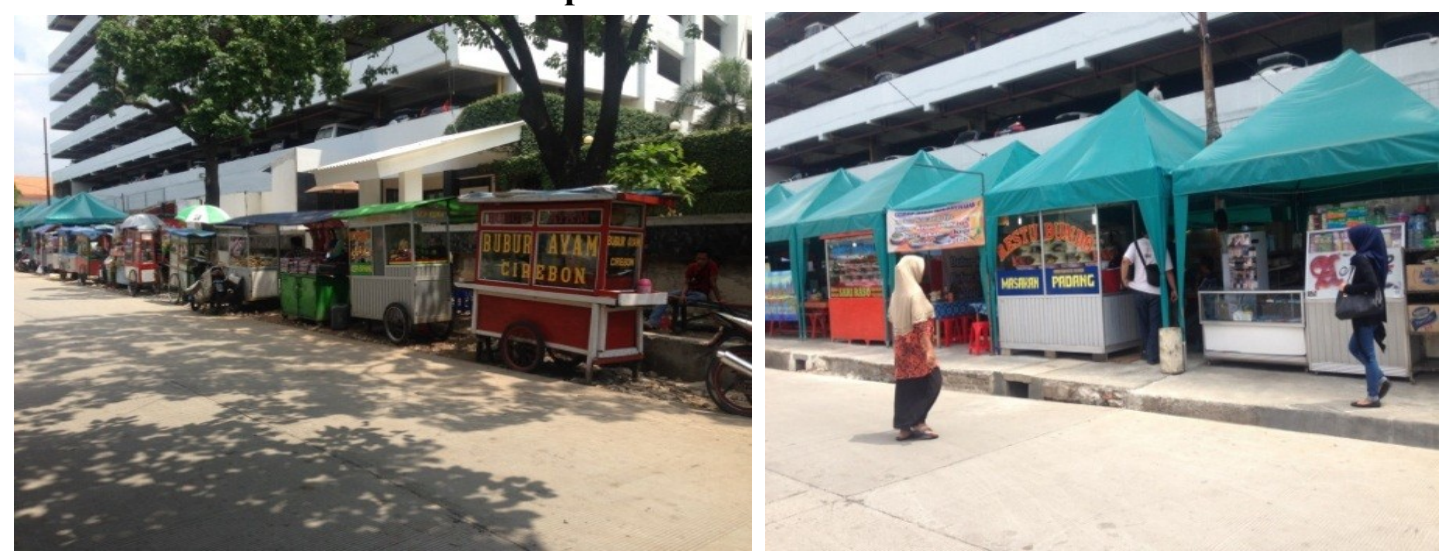

Gambar 2. Kondisi awal UMKM, sebelum dan sesudah penataan lokasi 


\section{Pembahasan Hasil Pengabdian}

Program pelatihan bagi UMKM telaah direncanakan cukup matang, namun dalam pelaksanaan belum sesuai dengan yang direncanakan. Kendala yan g dihadapi dating dari pelaku UMKM itu sendiri maupun tim PkM. Kendala berkaitan dengan masalah masalah teknis seperti waktu pelatihan yang sering diundur mengingat kesibukan masing masing pihak. Namun demikian secara keseluruhan pelatrihan dapat berjalan dengan lancer.

Evaluasi kegiatan dilakukan selama proses kegiatan berlangsung, yaitu pada saat peserta pelatihan mengikuti kegiatan di kelas. Selain itu, melakukan wawancara yaitu dengan memberikan berbagai pertanyaan yang terkait dengan pelaksanaan pelatihan berlangsung. Hal tersebut dilakukan untuk untuk mengetahui bagaimana tanggapan peserta tentang pelaksanaan kegiatan pelatihan kewiraausahaan dan perkoperasian yang telah dilaksanakan dan mengetahui sejauh mana ketercapaian pelaksanaan kegiatan pelatihan tersebut.

Dengan evaluasi ini, tim pelaksana kegiatan pelatihan atau tim pelaksana kegiatan pengabdian pada masyarakat dapat menyimpulkan bahwa kegiatan pelatihan kewirausahaan dan perkoperasian dapat meningkatkan penmgetahuan bagi pelaku UMKM Adapun pengetahuan yang dimiliki setelah mengikuti pelatihan kewirausahaan adalah sebagai berikut:

Pertama, para peserta pelatihan dapat mengetahui konsep dan inplementasi kewirausahaan. Tahap ini, tim pelaksana mempresentasikan materi pelatihan secara detail, para peserta menyimak hal-hal yang dipresentasikan tersebut dengan baik.

Hasil dari pelatihan kewirausahaan adalah meningkatnya wawasan pelaku UMKM Cempaka Putih yang sebelumnya belum begitu memahami konsep kewiaraausahaan, sekarang sudah mengetahui bahkan memahami sampai mempraktekanya.. Para peserta pelatihan begitu antusias dalam mengikuti pelatihan, hal ini dibuktikan dari banyaknya pertanyaanpertanyaan yang dilontarkan oleh peserta. Diharapkan dengan banyaknya pertanyaan tersebut, mereka lebih mengetahui secara detail dan mendalam bagaimana implementasi kewirausahaan. Selain melontarkan berbagai pertanyaan, mereka juga sangat antusias untuk melakukan praktik menghitung keuangan syariah Diharapkan dengan adanya kegiatan pelatihan ini dapat membantu para pelaku UMKM dalam melakukan usahanya.

\section{SIMPULAN}

Hasil kegiatan pelatihan bagi pelaku UMKM di Cempaka Putih dapat disimpulkan sebagai berikut.

a. Pelatihan ini dapat menambah pengetahuan tentang kewirausahaan dan perkoperasian berbasis syariahmulai dari pengertian, pemahaman tentang kewirausahaan dan perkoperasian berbasis syariah.

b. Diharapkan setelah pelatihan ini peserta dapat mengimplementasikan pengetahauan tentang kewirausahaan dan perkoperasian berbasis syariah kedalam praktek sehari hari.

c. Telah dilakukan penataan lokasi usaha sementara (loksem) UMKM yang tadinya tidak rapi menjadi lokasi usaha yang rapi dan bersih

d. Pelatihan kewirausahaan bagi pelaku usaha mikro UMKM ini sebaiknya ada tindak lanjutnya, untuk mengetahui sejauhmana perkembangan kinerja UMKM apakah para peserta menerapkan pengetahuan kewirausahaan yang diperoleh selama pelatihan.

\section{DAFTAR PUSTAKA}

Anggara, Cici. 2015. Coopetition Usaha Mikro Kelompok Usaha Mandiri Mayarakat (KUMM) Desa Bantar Kambing. $\quad$ http://cicianggara.co.id/2015/07/coopetitionusaha-mikro-kelompok-usaha.html (Diunduh 12 Oktober 2016)

Irawan, R. 2013. Aspek Perpajakan Usaha Mikro, Kecil dan Menengah. The 6th NCFB and Doctoral Colloquium, Unika Widya Mandala Surabaya.

Laporan tahunan Kementerian Koperasi dan Usaha Kecil dan Usaha Menengah, http://www.depkop.go.id/beritainformasi/data-informasi/laporan-tahunan/ (Diunduh 21 Oktober 2016) 
Pitra Sarosa, (2006), Becoming Yong Enterpreneur, Alex Media Competindo Tambunan, Tulus, (2012), Usaha Kecil dan Menengah di Indonesia:Beberapa Isu. Penting,Penerbit Jakarta; Salemba Empat Undang-Undang No. 20 Tahun 2008 tentang Usaha Mikro, Kecil dan
MenengahWarsono, S., E. Murti, A.Ridha dan A.Darmawan. 2010. Akuntansi UMKM Ternyata Mudah Dipahami dan Dipraktikkan 